\title{
Prevalence of Dental Caries among Children of Aged 6-12 Years in Tamilnadu - A Systematic Review
}

\author{
Suganya. $\mathbf{P}^{1}$, Rajmohan. $\mathbf{M}^{2}$, Bharathwaj. V. $V^{3}$, Sindhu. $\mathbf{R}^{3}$, \\ Dinesh Dhamodhar ${ }^{2}$, Shreelakshmi. $\mathrm{S}^{3}$, Prabu. $\mathrm{D}^{4}$, Prashanthy. M. $\mathrm{R}^{1}$ \\ ${ }^{1}$ Postgraduate Student, Department of Public Health Dentistry, SRM Dental College and Hospital, Ramapuram \\ ${ }^{2}$ Reader, Department of Public Health Dentistry, SRM Dental College and Hospital, Ramapuram \\ ${ }^{3}$ Senior Lecturer, Department of Public Health Dentistry, SRM Dental College and Hospital, Ramapuram \\ ${ }^{4}$ Head and Professor of the Department, Department of Public Health Dentistry, SRM Dental College and \\ Hospital, Ramapuram \\ Corresponding Author: Prabu. D
}

\begin{abstract}
Background: Dental caries is a serious public health problem in developed as well as developing nations, with high prevalence among children around the world. This systematic review of literature was undertaken to document the prevalence of dental caries.
\end{abstract}

Aims and Objectives: This study aims to evaluate the prevalence of dental caries among children of aged 6-12 years in Tamilnadu by conducting a systematic review.

Materials and Method: Studies evaluating the prevalence of dental caries among children of aged 6-12 years in the Tamilnadu were investigated. An extensive literature search was done in the following databases: Prospero, Grey literature, Science Direct, Cochrane library, Wiley online library, Lilacs and PubMed. The articles were retrieved from each database based on the MeSH representation. A modified version of the Newcastle-Ottawa Scale for crosssectional studies was used for assessment of the quality of the studies. A systematic literature search yielded 1034 publications from the various databases searched. According to the Preferred Reporting Items for systematic Reviews and Meta-Analyses and based on the inclusion and exclusion criteria, the final number of included studies was fifteen.

Results: Among the included studies, five studies were carried out in the Chennai district. Erode district was found to have the highest prevalence of dental caries at $89.3 \%$.
Conclusion: This review has reported a high prevalence of dental caries in Tamilnadu. None of the states reported prevalence below $30 \%$. The government should identify dental caries as a national priority which requires significant attention.

Keywords: Dental caries, Prevalence, Tamilnadu, Newcastle-Ottawa Scale.

\section{INTRODUCTION}

Oral health has always been an inseparable part of general health and affects the wellbeing of individuals. Dental caries remains a major public health problem among in most industrialized countries especially for those countries where preventive programs have not been established. WHO recently published a global review of oral health which emphasized that despite great improvements in the oral health of populations in several countries, still global problems persists. This is particularly so among underprivileged groups in both developing and developed countries [1].

Oral diseases such as dental caries, periodontal disease, tooth loss, oral mucosal lesions and oropharyngeal cancers, human immunodeficiency virus/acquired immunodeficiency syndrome (HIV/AIDS) related oral disease and oro-dental trauma 
Suganya. P et.al. Prevalence of dental caries among children of aged 6-12 years in Tamilnadu- a systematic review.

are major public health problems worldwide. Poor oral health may have a profound effect general health, and several oral diseases are related to chronic diseases (e.g. diabetes) [2]. Dental caries is the most prevalent chronic disease worldwide and the main cause of tooth loss among the population. Dental caries is an irreversible microbial disease characterized by demineralization of the inorganic portion and destruction of the organic substance of the tooth, which often leads to cavitations [1].

The multi-factorial etiology of caries allows of a number of different interpretations to account for changes in the prevalence of the disease with time, in both the developed and developing countries. These changes are variously ascribed to alterations in dietary habits, especially the consumption of sugar, variations in the patterns of dental hygiene, and increased contact with trace elements, especially fluoride in the environment, whether this might be due to ingestion or by local action within the mouth. Other factors are changes in the ecology and/or virulence of the oral and dental plaque microflora and alterations in the oral protective mechanisms including the immune status [3].

During the last five decades, measures to combat dental caries and periodontitis have been developed, tested and implemented in many populations around the world and are thought to have benefitted millions of people. Despite the huge effort made, a large part of the world's population still suffers from these two oral diseases, which are the main causes of tooth loss. Although effective methods are known for prevention and treatment of dental caries, it is a major health problem affecting mankind, in that its manifestations persist throughout life despite treatment [4]. The studies which estimate the prevalence of disease plays a crucial role in early diagnosis, prevention and treatment of diseases. Hence this present study aims to determine the prevalence of dental caries in
Tamilnadu by conducting a systematic review.

\section{MATERIALS AND METHOD}

In this study the systematic review of trials was carried out to evaluate the prevalence of dental caries in Tamilnadu

SEARCH STRATEGY: The articles related to the prevalence of dental caries in Tamilnadu were hand searched using electronic databases which includes Prospero, Grey literature, Science Direct, Lilacs, Cochrane library, Wiley online library and PubMed. The articles were retrieved from each database based on the $\mathrm{MeSH}$ representation "dental caries and prevalence”, “dental caries and Tamilnadu”.

\section{INCLUSION CRITERIA:}

- Original articles

- Articles with full text are included

- in vivo studies

\section{EXCLUSION CRITERIA:}

- Articles other than English language

- Review articles

- Search engine:

- Cochrane library

- Wiley online library

- Lilacs

- Prospero

- PubMed

- Science Direct

- Grey literature

This systematic review was conducted in agreement with Preferred Reporting Items for Systematic Reviews and Meta-Analyses (PRISMA). The protocol of this systematic review followed the Cochrane database of systematic reviews and the bias assessment of the articles was done by using modified version of the Newcastle-Ottawa scale [5] for crosssectional studies.

\section{RESULTS}

The figure 1 shows about the articles' eligibility for the study. Totally 1034 number of articles related to the 
Suganya. P et.al. Prevalence of dental caries among children of aged 6-12 years in Tamilnadu- a systematic review.

prevalence of dental caries was retrieved. 860 articles which outfit the eligibility criteria were excluded from the study.
Totally 174 number of articles with full text were assessed and finally 15 articles with full text were qualified for the study.

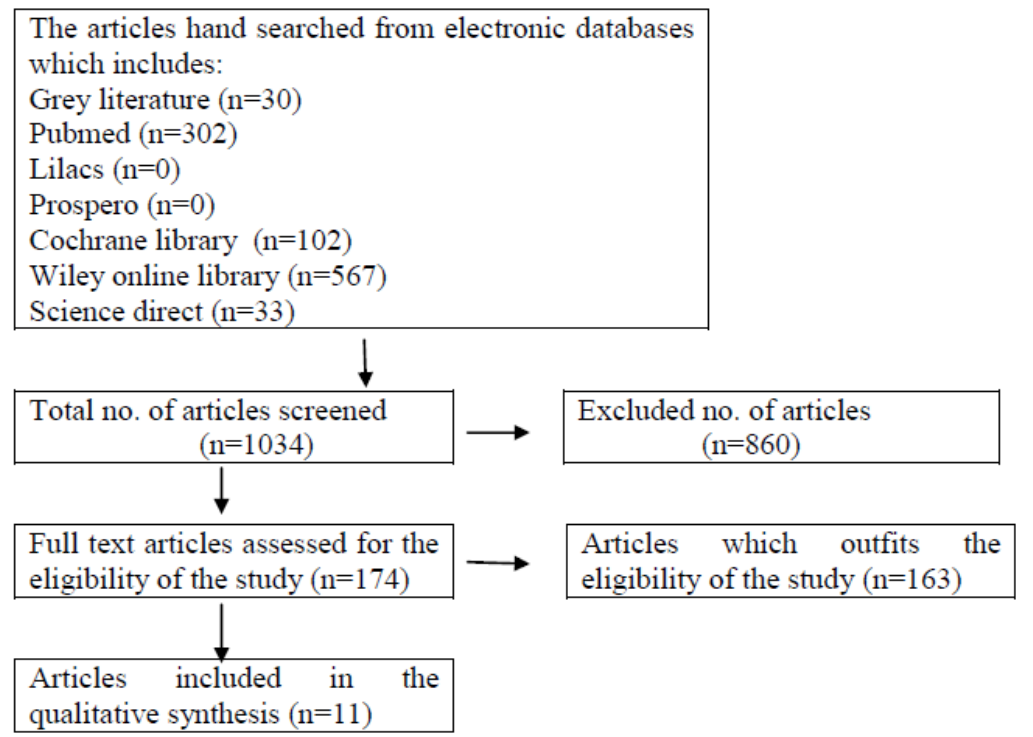

Figure 1: Flow diagram showing the number of studies identified, screened, assessed for eligibility, excluded and included in the systematic review

TABLE 1: Interventions of the study based on the prevalence of dental caries in Tamilnadu

\begin{tabular}{|l|l|l|l|l|l|l|}
\hline S.NO & AUTHOR & YEAR & STUDY AREA & Sample size & Age group & Index \\
\hline 1. & Mukesh kumar et al [6] & 2005 & Chennai & 1200 & 5 and 12 years & WHO Performa, 1999 \\
\hline 2. & Elangovan et al [7] & 2012 & Chennai & 510 & $6-12$ years & DMFT index \\
\hline 3. & Punitha et al [8] & 2015 & Chennai & 916 & $13-19$ years & DMFT index \\
\hline 4. & Ponnudurai et al [9] & 2016 & Chennai & 2796 & $6-14$ years & ICDAS II \\
\hline 5. & Abhirami Kannan [10] & 2017 & Sulur & 1945 & $6-12$ years. & DMFT index \\
\hline 6. & Cinku Angeline [11] & 2016 & Vedapatti & 500 & 12 years & DMFT index \\
\hline 7. & John eta al [12] & 2015 & Erode & 357 & $9-12$ years & DMFT index \\
\hline 8. & Saravannan et al [13] & 2003 & Chidambaram & 508 & $6-12$ years & DMFT index \\
\hline 9. & Joshi et al [14] & 2005 & Kanniyakumari & 700 & $6-12$ years & DMFT index \\
\hline 10. & Prabhu et al [15] & 2013 & Pudukottai & 657 & $6-12$ years & DMFT index \\
\hline 11. & Parasuraman et al [16] & 2016 & Tiruvallur & 357 & 5-10 years & DMFT index \\
\hline
\end{tabular}

Table 1 depicts the characteristics of the studies related to the prevalence of dental caries in Tamilnadu

\begin{tabular}{|c|c|c|c|c|c|}
\hline S.NO & AUTHOR & YEAR & $\begin{array}{l}\text { TYPE } \\
\text { OF } \\
\text { STUDY }\end{array}$ & INTERVENTION & OUTCOME \\
\hline 1. & $\begin{array}{l}\text { Mukesh } \\
\text { kumar et al } \\
\text { [6] }\end{array}$ & 2005 & $\begin{array}{l}\text { Cross- } \\
\text { sectional } \\
\text { study }\end{array}$ & $\begin{array}{l}1200 \text { children were selected from } 30 \text { schools of } \\
\text { aged } 5 \text { and } 12 \text { years in Chennai city and their } \\
\text { oral health status were examined by using } \\
\text { WHO, } 1999 \text { oral health assessment }\end{array}$ & $\begin{array}{l}\text { The prevalence of dental caries } \\
\text { among } 12 \text { years old children was } \\
37.5 \%\end{array}$ \\
\hline 2. & $\begin{array}{l}\text { Elangovan et } \\
\text { al [7] }\end{array}$ & 2012 & $\begin{array}{l}\text { Cross- } \\
\text { sectional } \\
\text { study }\end{array}$ & $\begin{array}{l}510 \text { school children of aged } 6-12 \text { years were } \\
\text { selected. The dental caries was examined and } \\
\text { their association with body mass index and diet } \\
\text { was assessed }\end{array}$ & $\begin{array}{l}\text { Overall prevalence of dental caries } \\
\text { was } 78.6 \%\end{array}$ \\
\hline 3. & $\begin{array}{l}\text { Punitha et al } \\
\text { [8] }\end{array}$ & 2015 & $\begin{array}{l}\text { Cross- } \\
\text { sectional } \\
\text { study }\end{array}$ & $\begin{array}{l}916 \text { adolescent school children of aged } 13-19 \\
\text { years from urban areas in Chennai were } \\
\text { selected. The dental caries was examined and } \\
\text { their association with dietary habits was } \\
\text { assessed }\end{array}$ & $\begin{array}{l}\text { Overall prevalence of dental caries } \\
\text { was } 36.7 \% \text { and it was highly } \\
\text { significant among children who } \\
\text { frequently consumed more } \\
\text { carbonated drinks and confectionery } \\
\text { items }\end{array}$ \\
\hline 4. & $\begin{array}{l}\text { Ponnudurai et } \\
\text { al [9] }\end{array}$ & 2016 & $\begin{array}{l}\text { Cross- } \\
\text { sectional } \\
\text { study }\end{array}$ & $\begin{array}{l}2796 \text { school children of aged 6-14 years from } \\
\text { pallikaranai were selected. Dental caries was } \\
\text { assessed by using ICDAS II }\end{array}$ & $\begin{array}{l}\text { The overall prevalence of dental } \\
\text { caries was } 68.8 \% \text { and it was more } \\
\text { common among females. }\end{array}$ \\
\hline 5. & $\begin{array}{l}\text { Abhirami } \\
\text { Kannan [10] }\end{array}$ & 2017 & $\begin{array}{l}\text { Cross- } \\
\text { sectional } \\
\text { study }\end{array}$ & $\begin{array}{l}\text { The prevalence of dental caries was assessed } \\
\text { among } 1945 \text { students of aged 6-12 years. }\end{array}$ & $\begin{array}{l}78 \% \text { of females and } 72 \% \text { males had } \\
\text { dental caries. }\end{array}$ \\
\hline
\end{tabular}


Suganya. P et.al. Prevalence of dental caries among children of aged 6-12 years in Tamilnadu- a systematic review.

\begin{tabular}{|l|l|l|l|l|l|}
\hline \multicolumn{2}{|l|}{ Table 2 Continued... } \\
\hline 6. & $\begin{array}{l}\text { Cinku } \\
\text { Angeline [11] }\end{array}$ & 2016 & $\begin{array}{l}\text { Cross- } \\
\text { sectional } \\
\text { study }\end{array}$ & $\begin{array}{l}\text { 500 children of aged 12 years were recruited. } \\
\text { Their dental caries status was assessed using } \\
\text { DMFT index }\end{array}$ & $\begin{array}{l}\text { The overall prevalence of dental } \\
\text { caries was 76.9\% }\end{array}$ \\
\hline 7. & $\begin{array}{l}\text { John et al } \\
{[12]}\end{array}$ & 2015 & $\begin{array}{l}\text { Cross- } \\
\text { sectional } \\
\text { study }\end{array}$ & $\begin{array}{l}\text { The prevalence of dental caries among tribal, } \\
\text { suburban and urban areas of government school } \\
\text { children of aged 9-12years in Erode district and } \\
\text { elaborated about the association of dental caries } \\
\text { with race, educational status, income and media } \\
\text { among these three groups. The dental caries was } \\
\text { assessed using DMFT index }\end{array}$ & $\begin{array}{l}\text { Therall prevalence of dental } \\
\text { caries was found to be 89.3\%. }\end{array}$ \\
\hline 8. & $\begin{array}{l}\text { Saravannan et } \\
\text { al [13] }\end{array}$ & 2003 & $\begin{array}{l}\text { Cross- } \\
\text { sectional } \\
\text { study }\end{array}$ & $\begin{array}{l}\text { 508 rural school children of aged 6-12 years } \\
\text { were recruited and the dental caries were } \\
\text { examined using DMFT index }\end{array}$ & $\begin{array}{l}\text { The overall prevalence of dental } \\
\text { caries was found to be 71.7\% }\end{array}$ \\
\hline 9. & $\begin{array}{l}\text { Joshi et al } \\
{[14]}\end{array}$ & 2005 & $\begin{array}{l}\text { Cross- } \\
\text { sectional } \\
\text { study }\end{array}$ & $\begin{array}{l}\text { 700 school children of aged 6-12 years were } \\
\text { recruited. Their dental caries status was } \\
\text { examined using DMFT index. }\end{array}$ & $\begin{array}{l}\text { The overall prevalence of dental } \\
\text { caries was 77\%. }\end{array}$ \\
\hline 10. & $\begin{array}{l}\text { Prabhu et al } \\
{[15]}\end{array}$ & 2013 & $\begin{array}{l}\text { Cross- } \\
\text { sectional } \\
\text { study }\end{array}$ & $\begin{array}{l}\text { 657 children of aged 6- 12 years were recruited. } \\
\text { Their dental caries status was evaluated using } \\
\text { DMFT index }\end{array}$ & $\begin{array}{l}\text { The overall prevalence of dental } \\
\text { caries was 87.2\% }\end{array}$ \\
\hline 11. & $\begin{array}{l}\text { Parasuraman } \\
\text { et al [16] }\end{array}$ & 2016 & $\begin{array}{l}\text { Cross- } \\
\text { sectional } \\
\text { study }\end{array}$ & $\begin{array}{l}\text { 357 children of aged 5-10 years were recruited } \\
\text { and the status of dental caries was assessed } \\
\text { using DMFT index. }\end{array}$ & $\begin{array}{l}\text { The prevalence of dental caries was } \\
63.9 \% .\end{array}$ \\
\hline
\end{tabular}

Table 2 depicts the outcome of the studies related to the prevalence of dental caries in Tamilnadu

TABLE 3: BIAS ASSESSMENT

\begin{tabular}{|c|c|c|c|c|c|c|c|}
\hline \multirow[t]{2}{*}{ Author name } & \multicolumn{4}{|l|}{ Selection } & \multirow[t]{2}{*}{ Comparability } & \multicolumn{2}{|c|}{ Outcome/ exposure } \\
\hline & $\begin{array}{l}\text { Sample } \\
\text { representation }\end{array}$ & $\begin{array}{l}\text { Sample } \\
\text { size }\end{array}$ & $\begin{array}{l}\text { Non- } \\
\text { respondents }\end{array}$ & $\begin{array}{l}\text { Risk } \\
\text { factor }\end{array}$ & & $\begin{array}{l}\text { Assessment of } \\
\text { outcome }\end{array}$ & $\begin{array}{l}\text { Statistical } \\
\text { test }\end{array}$ \\
\hline $\begin{array}{l}\text { Mukesh kumar et } \\
\text { al; } 2005 \text { [6] }\end{array}$ & $*$ & - & $*$ & * & $*$ & - & $*$ \\
\hline $\begin{array}{ll}\text { Elangovan } & \text { et } \\
\text { al;2012 [7] } & \\
\end{array}$ & $*$ & - & * & * & * & - & * \\
\hline $\begin{array}{l}\text { Punitha et al;2015 } \\
\text { [8] }\end{array}$ & - & - & * & $*$ & * & - & * \\
\hline $\begin{array}{ll}\text { Ponnudurai } & \text { et } \\
\mathrm{al} ; 2016[9] & \\
\end{array}$ & * & - & - & * & * & - & * \\
\hline $\begin{array}{l}\text { Abhirami Kannan; } \\
2017 \text { [10] }\end{array}$ & - & - & * & * & * & - & * \\
\hline $\begin{array}{l}\text { Cinku Angeline; } \\
2016 \text { [11] }\end{array}$ & - & - & * & * & * & - & * \\
\hline $\begin{array}{l}\text { John et al; } 2015 \\
{[12]}\end{array}$ & * & - & * & $*$ & * & - & * \\
\hline $\begin{array}{l}\text { Saravannan et al; } \\
2003 \text { [13] }\end{array}$ & - & - & - & $*$ & * & - & * \\
\hline $\begin{array}{l}\text { Joshi et al; } 2005 \\
{[14]}\end{array}$ & - & - & * & * & * & - & * \\
\hline $\begin{array}{l}\text { Prabhu et al; } 2013 \\
\text { [15] }\end{array}$ & - & - & * & * & * & - & * \\
\hline $\begin{array}{l}\text { Parasuraman et al; } \\
2006 \text { [16] }\end{array}$ & * & - & * & * & * & - & * \\
\hline
\end{tabular}

\section{DISCUSSION}

Kumar et al in 2005 had discussed about the oral health status among school children of age 5 and 12 years in Chennai. The oral health was analyzed among 1200(600 private and 600 corporation school) children from 30 schools. Dental caries was most prevalent and it was common in permanent teeth when compared to primary teeth and it was also more in corporation school children when compared to private school children this might be due to varying socioeconomic status. On gender analysis, there was no significant difference in dental caries. The prevalence of dental caries was highest among 12 year old children when compared to 5 year old children. On gingival assessment among 5 year old children, $80 \%$ had good oral hygiene and $2 \%$ had poor oral hygiene with greater male predilection and there was no statistically significant difference between corporation and private schools $(p=0.44)$. Among 12 year old children, there was a 
highly statistically significant $(\mathrm{p}=0.008)$ among boys when compared to girls. Higher percentage of corporation school children had gingival and periodontal problems when compared to private school children. Diastema, maxillary and mandibular over jet and antero-posterior relationship shows statistically significant. The prevalence of dental opacities among 5 years old was $28.3 \%$ and in 12 year old it was $23.3 \%$. There was a statistically significant difference in 5 years between boys and girls $(p=0.02)$ and schools $(p=0.04)$. No significant difference between age and schools among 12 year old children. The prevalence of dental fluorosis was $1 \%$ among 5 years old and it was 2.5\% in 12 year old children. Fluorosis was not significant in both ages. The percentage of dental caries, gingival and periodontal problems was most common among corporation schools when to private schools this might be due to inequalities and variation of socioeconomic status. The government should address these inequalities before oral health schemes are planned [6].

Elangovan et al in 2012 had discussed about the association between diet, Body Mass Index (BMI), and dental caries among 6-12 years old school children in Chennai. The data was collected by using anthropometric measurements, BMI, diet chart and dental caries was recorded among 510 children of these $113(22.15 \%)$ children was underweight BMI- for-age category, 249(48.82\%) was normal BMI, 88(17.25) comes under overweight category and $60(11.76)$ of them comes under obese category. On gender analysis, there was no statistically significant difference $(p>0.05)$. Consumption of daily intake of fatty foods and oily items was statistically significant for all BMI for age $(\mathrm{p}<0.05)$ expect between overweight and obese $(\mathrm{p}=0.21)$. There was a statistically significant difference in daily consumption of snacks was found for all BMI for age $(\mathrm{p}<0.05)$ except between overweight and obese children $(p=0.27)$. The prevalence of dental caries was $78.6 \%$.
No statistically significant difference in daily intake of other food groups between various BMI for age $(\mathrm{p}>0.05)$. There was a statistically significant difference was found between dental caries and consumption of snack items $(\mathrm{p}<0.01)$ and there was no significant difference between dental caries and other food groups ( $p>0.05)$ concluded that the dental caries and the consumption of fatty foods and snacks was more with obese children when compared to others [7].

Punitha et al in 2015 had discussed about the association of dental caries and frequency intake of dietary habits among adolescents of urban school children of aged 13-19 years. The cross-sectional study was conducted on adolescent children $(n=916)$ and the data was collected using questionnaire regarding demographic data, dietary intake and frequency. The prevalence of dental caries was $46.7 \%$. No statistically significant difference was found between dental caries and type of diet $(\mathrm{p}=0.07)$, skipping of meals $(\mathrm{p}=0.86)$, frequency of eating in fast food stalls $(\mathrm{p}=0.86)$ and snacking in between meals $(\mathrm{p}=0.08)$. DMFT values were higher among non-vegetarians and among children snacking in between meals. The frequent intake of carbonated drinks and confectionery was higher among children with caries when compared to caries free children $(p=0.000)$. There was a statistically significant correlation was found between dental caries and frequent intake of carbonated drinks and confectionery concluded that intake of carbonated drinks and confectionery was harmful and causes demineralization of the tooth surfaces which leads to formation of dental caries [8].

Ponnudurai et al in 2016 had discussed about the prevalence of dental caries among school children of aged 614years in Pallikaranai. The assessment of dental caries was done based on ICDAS II. The prevalence of dental caries was $57 \%$ among 6 year old children, $67 \%$ in 7 year old, $63 \%$ in 8 year old, $74 \%$ in 9 year old, $76 \%$ in 10 year old, $74 \%$ in 11 year old, $69 \%$ in 12 year old, $71 \%$ in 13 year old and 
Suganya. P et.al. Prevalence of dental caries among children of aged 6-12 years in Tamilnadu- a systematic review.

69\% among 14 year old school children. The overall prevalence of dental caries was $68.8 \%$. The caries associated with sealants and restoration (CARS) was $1.4 \%$. On gender analysis, there was no significant difference. Dental caries increases with increasing age might be due to the eruption of new teeth which become decayed due to poor oral hygiene [9].

Abhirami Kannan et al in 2017 has discussed about the prevalence of dental caries among the private school children in Sulur. The dental status and the need of their follow up was assessed among 1945 students of these $28 \%$ of children had dental problems of which $78 \%$ of females and $72 \%$ males had dental caries, $15 \%$ malocclusion in both gender, stains was $8 \%$ in females and $13 \%$ in males and the follow up treatment for the above conditions was $59 \%$ males and $65 \%$ females need restoration for dental caries, $12 \%$ females and $13 \%$ males required extraction, $14 \%$ female and $15 \%$ male requires orthodontic treatment where myofunctional appliance was advised for $1 \%$ children of both male and females concluded that the dental caries prevalence was higher among these populations when compared to other dental problems with greater female predilection. There was a disparity existing in creating awareness among these populations. Awareness of dental education, proper brushing techniques and importance of regular dental checkups should be given to the parents and teachers so that they can explain it in a better way to the students in order to provide adequate knowledge about the importance of oral hygiene [10].

Cinku Angeline et al in 2016 has discussed about the prevalence of dental caries among rural children and elaborated about the effectiveness of teaching dental hygiene among school children in Vedapatti. There is a statistically significant difference was found in dental caries between the pre and post teaching of dental hygiene among these students. There was an association between the dental caries oral hygiene practices and concluded that the awareness of oral hygiene practices provides the better way to prevent and control dental caries. Proper dental education programs and dental camps should be conducted to these schools to create awareness of dental problems and treatment needs [11].

John et al in 2015 had discussed about the prevalence of dental caries among tribal, suburban and urban areas of government school children of aged 912years in Erode district and elaborated about the association of dental caries with race, educational status, income and media among these three groups. The prevalence of dental caries was $89.3 \%$. There was a statistically significant difference in DMFT score among these three groups $(p=0.001)$. The percentage of dental caries prevalence was higher in trial school children followed by suburban and urban school children. There was a statistically significant difference in dental caries was found based on brushing frequency $(\mathrm{p}=0.001)$, mother's educational status $(\mathrm{p}=0.018)$ and there is no statistically significant difference in dental caries was found based on media and economic status. There was a disparity exists in the prevalence of dental caries among these three groups concluded that the lack of knowledge, awareness and practice of oral hygiene and improper brushing technique paves the way for the dental caries prevalence. The skewedness in the poverty, health educational programmes and oral health schemes among these three groups are the major issues and it should be planned properly [12].

Saravannan et al in 2003 had discussed about the prevalence of the dental caries among rural school children in Chidambaram and also elaborated about the importance in the treatment of dental caries. The dental caries was examined among 508 rural school children their dental caries prevalence was highest in deciduous teeth (71.7\%) when compared to the permanent teeth (26.5\%). The mean dmft and DMFT scores was 3.00 and 0.42 . The mean $\mathrm{dmft}$ score decreased with age $(p<0.01)$ whereas 
it was increased in mean DMFT $(\mathrm{p}<0.001)$. On gender analysis, there was no significant difference in dmft whereas there was a significant difference in DMFT score among girls $(\mathrm{p}<0.02)$ than boys. Out of 508 children examined, 308(60.6\%) children need one surface restoration, 224(44.1\%) children needed two surface restoration, $109(21.5 \%)$ of them needed extraction, $303(59.6 \%)$ of children need preventive care, $11.4 \%$ needed fissure sealant,7.3\% needed crown placement whereas $2.6 \%$ need pulp care. Majority of these children has only decayed teeth when compared with missing and restoration, indicating that there is a lack of willingness and knowledge on the importance of the dental health. The expansion of oral health programmes must be ensured to these areas and the oral hygiene measures are properly explained to the teachers and parents so that they can teach the students in a effective manner to prevent dental caries [13].

Joshi et al in 2005 had discussed about the prevalence of dental caries among rural areas of government primary school children aged 6-12years in Kulashekharam and elaborated that the improper brushing techniques, dietary habits and their attitude towards dentists are the most important cause for the occurrence of dental caries. The prevalence of dental caries was $77 \%$. There was no statistically significant difference was found between dental caries exposure and gender. On gender analysis, girls had a significantly higher sweet snacking habits than boys $(p<0.02)$. There was a high significant difference among boys and girls in their knowledge about dental caries and their fear of dentists. Boys exhibited more knowledge about dental caries and less fear towards dentists as compared to girls. The knowledge and awareness need to be generated towards oral health and the importance of regular dental checkups should be properly explained to these areas through expansion of oral health schemes [14].

Prabhu et al in 2013 had discussed about the prevalence of dental caries among adults in Pudukottai and also elaborated about the awareness of the population regarding dental problems. The overall prevalence of dental caries was $87.2 \%$ and it was high among aged patients. $27.9 \%$ of population was using tobacco. There was a statistically significant association was found between tobacco consumption and dental caries $(\mathrm{P}=0.026)$ and also there was a lack of willingness to quit the habit.95.6\% of them had brushed their teeth daily. Awareness about good and bad dental practices was found to be low. One fifth of the individuals with dental problems relied on home remedies. Proper measures should be taken to encourage these peoples about the dental care services and provide adequate facilities to them for easy access of dental checkup [15].

Parasuraman et al in 2016 had discussed about the prevalence of dental caries among school children of aged 5-10 years in Thirumazhisai and elaborated about the association of the factors influencing dental caries. The dental caries was examined among 357 children and their prevalence was $63.9 \%$. Higher prevalence of dental caries was found among the girls (54\%), among the lower socioeconomic class (41.7\%), among those who consumed mixed diet (74.8\%), among those who consumed junk foods $(62.6 \%)$ at least once every day and among those who consumed dairy products $(58.9 \%)$ at least once every day. Dental caries was found to be low in prevalence among those who consumed fruits several times a week (6.1\%), among those who brushed their teeth twice/more than twice a day (20.2\%) and among those who washed their mouth after each meal (38.7\%) concluded there was a significant association in dental caries was found between socioeconomic status, consumption of junk foods, dairy products, oral hygiene practices [16].

Lack of awareness, improper dietary habits and poor oral hygienic practices are the contributing factors for the development of dental caries. Dental caries is a preventable disease which can be alleviated 
Suganya. P et.al. Prevalence of dental caries among children of aged 6-12 years in Tamilnadu- a systematic review.

by creating community awareness through health education activities. The limitations of this study are other databases should also be considered to get more relevant outcome. Many studies have been excluded due to fulfilling the criteria in extracting the control groups and the appropriate reason was not explained in detail. Only limited number of studies is available regarding the prevalence of dental caries. Studies were not conducted in many districts of Tamilnadu. Further more research should be conducted to obtain the appropriate results.

\section{CONCLUSION}

This study concludes that the dental caries prevalence was more in Tamilnadu. Among the included studies, five studies were carried out in the Chennai district. Pudukottai district was found to have the highest prevalence of dental caries at $87.2 \%$, and the lowest prevalence was reported in Coimbatore (43.6\%). This review has reported a high prevalence of dental caries in Tamilnadu. None of the states reported prevalence below $40 \%$. The government should identify dental caries as a national priority which requires significant attention.

\section{Acknowledgement: None}

\section{Conflict of Interest: None}

\section{Source of Funding: None}

\section{REFERENCES}

1. Mittal M, Chaudhary P, Chopra R, Khattar V. Oral health status of 5 years and 12 years old school going children in rural Gurgaon, India: an epidemiological study. Journal of Indian Society of Pedodontics and Preventive Dentistry. 2014 Jan 1;32(1):3.

2. Almoudi MM, Hussein AS, Abu Hassan MI, Schroth RJ. Dental caries and vitamin D status in children in Asia. Pediatrics International. 2019; 61(4):327-38.

3. Winter GB. Epidemiology of dental caries. Archives of Oral Biology. 1990; 35: S1-7.

4. Frencken JE, Sharma P, Stenhouse L, Green D, Laverty D, Dietrich T. Global epidemiology of dental caries and severe periodontitis-a comprehensive review. Journal of clinical periodontology. 2017;44 (Suppl 18):S94-105.

5. Ganesh A, Muthu MS, Mohan A, Kirubakaran R. Prevalence of early childhood caries in India-a systematic review. The Indian Journal of Pediatrics. 2019 Mar;86(3):276-86.

6. Kumar PM, Joseph T, Varma RB, Jayanthi $M$. Oral health status of 5 years and 12 years school going children in Chennai city-An epidemiological study. Journal of Indian Society of Pedodontics and Preventive Dentistry. 2005; 23(1):17.

7. Elangovan A, Mungara J, Joseph E. Exploring the relation between body mass index, diet, and dental caries among 6-12year-old children. Journal of Indian Society of Pedodontics and Preventive Dentistry. 2012; 30(4):293-300.

8. Punitha VC, Amudhan A, Sivaprakasam P, Rathanaprabu V. Role of dietary habits and diet in caries occurrence and severity among urban adolescent school children. Journal of pharmacy \& bioallied sciences. 2015;7(Suppl 1):S296-S300.

9. Ponnudurai Arangannal SK, Jayaprakash J. Prevalence of dental caries among school children in Chennai, based on ICDAS II. Journal of clinical and diagnostic research: JCDR. 2016;10(4):ZC09-12.

10. Kannan A, Govindarajan V. prevalence of dental caries among school children in Sulur- Coimbatore. Journal of Evidence Based Medicine and Healthcare. 2017; 4(82):4868-70.

11. Cinku Angeline S. Prevalence of dental caries among rural children and effectiveness of playway method of teaching on dental hygiene in selected school children at PSG high school, vedapatti, Coimbatore. Global Journal for research analysis.2017;3(2):3562-67.

12. John JB, Asokan S, Aswanth KP, Priya PG, Shanmugaavel AK. Dental caries and the associated factors influencing it in tribal, suburban and urban school children of Tamil Nadu, India: a cross sectional study. Journal of public health research. 2015; 4(1):361-67.

13. Saravanan S, Kalyani V, Vijayarani MP, Jayakodi P, Felix JW, Arunmozhi P, Krishnan V, Kumar PS. Caries prevalence and treatment needs of rural school children 
Suganya. P et.al. Prevalence of dental caries among children of aged 6-12 years in Tamilnadu- a systematic review.

in Chidambaram Taluk, Tamil Nadu, South India. Indian Journal of Dental Research. 2008;19(3):186-190.

14. Joshi N, Rajesh R, Sunitha M. Prevalence of dental caries among school children in Kulasekharam village: A correlated prevalence survey. Journal of Indian Society of Pedodontics and Preventive Dentistry. 2005;23(3): 138-40.

15. Prabhu N, Jeevitha T, Gayathri V, Pirabu RA, Ram PV. Prevalence of dental caries among adults and elderly in an urban population of Pudukkottai, India. Journal of Evolution of Medical and Dental Sciences. 2013;2(50):9806-12.
16. Parasuraman G, Krishna YG, Kaviya M, Jain NA, Rajendiran P, Dutta R. A study on the prevalence of dental caries among the school going children in Tamil Nadu. Int $\mathrm{J}$ Community Med Public Health. 2017;10: 3582-89.

How to cite this article: Suganya. P, Rajmohan. M, Bharathwaj. V. V et.al. Prevalence of dental caries among children of aged 6-12 years in Tamilnadu- a systematic review. International Journal of Science \& Healthcare Research. 2021; 6(4): 177-185. DOI: https://doi.org/10. 52403/ijshr.20211025 